\title{
UM "NÓS" INTERCESSOR: QUANDO A ETNOGRAFIA TAMBÉM É MAGIA
}

\author{
Luiza Dias Flores ${ }^{1}$
}

${ }^{1}$ Universidade Federal do Amazonas (UFAM), Manaus/AM, Brasil

Antes de tudo, é preciso contextualizar. ${ }^{1}$ Este artigo é derivado do trabalho de campo da minha pesquisa de doutorado que teve início em 2016. A tese escrita é fruto do que chamei "composição contracolonizadora"2, pois implicou um duplo convite: primeiro, feito por mim às fundadoras da comunidade kilombola ${ }^{3}$ Morada da Paz para realizar com elas uma pesquisa de doutorado; segundo, em contrapartida à minha proposta, feita por elas a mim, para me tornar uma ia $\hat{o}^{4}$ da comunidade. Disseram-me: "A tese já está pronta. Quem precisa estar pronta é você". Ambos os convites foram concomitantemente aceitos. Não me deterei nesta questão bastante complexa, mas é importante à leitora e ao leitor que tenha essa relação como pano de fundo: meu trabalho de campo se iniciou paralelo à minha iniciação como iaô - relação esta que se alterou ao longo do tempo.

A Comunidade Kilombola Morada da Paz, situada em Triunfo/RS, é formada majoritariamente por mulheres negras e foi certificada pela Fundação Cultural Palmares como quilombo em 2016. A Morada da Paz, também conhecida como Território de Mãe Preta, é uma comunidade espiritual "afrobudígena", pois implica a articulação do budismo tibetano Mahayana, o xamanismo Mbyá-Guarani e as religiões de matriz africana, incluindo Batuque, Candomblé e Umbanda - composições sobre as quais desenvolverei oportunamente em outro artigo. O fundamental para o argumento que desejo desenvolver aqui é que as pessoas que lá residem são consideradas filhas de uma preta-velha, Mãe Preta, e de um exu, Seu Sete, que guiam e orientam os caminhos da comunidade e de suas integrantes junto com outras entidades (Orixás, caboclos, pretos-velhos, ciganos, mestres ascencionados, vedas, entre outros). Ao lado de e amparada pelas entidades, desenvolvem uma série de trabalhos com a comunidade do entorno e da região metropolitana de Porto Alegre de educação afro-brasileira e ambiental com crianças, adolescentes e adultos. 
Para a Morada, tudo o que ocorre no mundo faz parte do que chamam espiritualidade e guerra cósmica ${ }^{5}$ e minha presença no local e a escrita da tese não foram percebidas como externas a isso. O mundo é habitado por seres e forças invisíveis, que povoam o cosmos e que engendram e atuam no que chamamos de 'realidade' e 'materialidade' - nos corpos, nas situações, nos espaços, no que nomeamos 'estrutura social', ou até mesmo 'política'. A percepção de guerra cósmica parte da ideia de que "a espiritualidade não tem lado", como me ensinou Yashodhan, mestra e líder espiritual da comunidade, ou seja, estas forças e esses seres invisíveis podem ser de potência, "das luzes", ou destrutivas, "energias densas", que servem "às trevas".

Não é possível reduzir a ideia de forças das trevas e forças das luzes aos termos cristãos Deus e Diabo ou Bem e Mal. Primeiro, porque tanto em um quanto em outro não há a existência de figuras únicas. São os "propósitos comuns", explicam-me as Yas ${ }^{6}$, entre diferentes forças, entidades e seres que possibilitam a unidade. O que formam essas duas forças, que constituem dois mundos em guerra, são as relações que consolidam e ao que servem. É possível que um mesmo sujeito se conecte com esses dois mundos, fazendo do corpo um território em disputa - como, por exemplo, o adoecimento e a cura. Por isso, continuamente, as Yas nos alertam para a necessidade de vigiar nossas ações, nossos pensamentos e sentimentos, para não "dar passagem" a elementos e seres que trabalham para as "forças das trevas".

Suas designações são anteriores, na medida em que sabem que forças das trevas e forças das luzes agem sobre o mundo visível, mas elas só são dadas a conhecer quando se encontram com os sujeitos que, então, as designam. São percebidas pelos efeitos que produzem, sejam eles benéficos ou nefastos - diria, então, que estes podem ser entendidos como bons encontros e maus encontros, nos termos propostos por Spinoza (2009; ver também Deleuze 2002, 2017). Quero dizer com isto que é importante diferenciarmos as luzes e as trevas dos valores moralizantes e transcendentes para pensá-los segundo diferenças qualitativas dos modos de existência. O bom encontro ocorre quando "um corpo compõe diretamente a sua relação com o nosso e, com toda ou com uma parte de sua potência, aumenta a nossa", produzindo paixões, ou afetos, alegria e fortalecendo nossa potência de agir. O mau encontro pauta-se, ao contrário, pela decomposição. É quando um corpo, ao nos encontrar, decompõe a relação do nosso, apesar de compor com as nossas partes, "mas sob outras relações que aquelas que correspondem à nossa essência", ${ }^{7}$ produzindo paixões tristes, diminuindo nossa potência de agir. São ambas consequências de afecções passivas, porque se explicam por um corpo exterior que nos afeta. 
Nessa guerra cósmica há, sem dúvida, um esforço da Morada para organizar, ao máximo, encontros que produzam paixões alegres e o intuito de fazer da nossa relação, e da pesquisa que dela deriva, um bom encontro. Dessa forma, tanto o trabalho de campo quanto a escrita foram acompanhadas minuciosamente pelos cinco mais velhos (quatro mulheres e um homem) e fundadores da comunidade, elas conhecidas como Yas (as mães) e ele como Baba (o pai).

Desde o início do meu envolvimento, as Yas mostraram-se bastante interessadas em acompanhar o desenvolvimento do meu trabalho de escrita. Os motivos pareciam ser variados: interesses nas trocas de saberes; acompanhamento de como a Morada será apresentada para a Universidade e como seus saberes serão descritos e postos em relação com os conhecimentos acadêmicos; e acompanhar o cuidado que devo ter com a palavra, visto que ali entendem que "a palavra é magia". A prerrogativa desse cuidado é, sobretudo, a fabricação coletiva de um "nós e outros", em função da guerra cósmica em curso que, por sua vez, incide sobre a clássica relação 'nós e outros' da Antropologia.

\section{Os acessos}

A pesquisa foi construída num contexto em que não me era possível andar com caderno de anotações e caneta a fazer perguntas ou, simplesmente, tomar nota simultaneamente com um determinado evento que acontecia na comunidade devido à rotina diária da comunidade na qual eu estava envolvida. Isto teve consequências no modo com que conduzi a composição dos meus cadernos de campo. O tempo que eu tinha em Porto Alegre, dois dias na semana, eu utilizava para escrever. Escrevia exaustivamente o que havia registrado em minha memória. Vez ou outra, quando achava que certas colocações eram muito importantes de registrar, corria ao caderno para anotar. As falas mais longas que aqui apresento foram obtidas durante os ipadês, rodas de conversas, nos quais conseguia registrar em papel com mais detalhamento.

Não foram poucos os momentos em que eu fiquei bastante nervosa com essa situação e também com a dificuldade de obter informações que eu julgava necessárias para a escrita. Às vezes, diziam-me que o contexto não era propício para as minhas perguntas, pois demandavam uma outra atenção para elaborar as respostas; em outras, o tempo era muito restrito para que eu pudesse realizá-las. Certa vez, em um momento de incômodo, comentei com uma egbomi (irmã mais velha) o fato de eu nunca 
conseguir perguntar. Ela me respondeu que os momentos ideais eram os ipadês, rodas de conversa em que cada participante pede o seu agoyê mojubá, o "axé de fala e de escuta", permitindo que haja uma sustentação energética para o diálogo que se estabelecerá. De fato, o ipadê foi a principal metodologia utilizada na composição desta etnografia, tanto para obter respostas às minhas perguntas e para ouvir narrativas mais prolongadas quanto para ter ciência de uma série de acontecimentos da comunidade que não pude presenciar.

Porém, muitas vezes, nos reuníamos em ipadês para discutir assuntos urgentes e o tempo não permitia que eu fizesse as perguntas que eu julgava necessárias para a pesquisa. A egbomi reavaliou sua colocação e comentou que não havia problemas de eu perguntar fora dos ipadês, mas era importante que eu atentasse para os campos energéticos e os sentisse para ver se permitiriam ou não que eu fizesse as perguntas. "Se estamos cozinhando e você me pergunta algo sobre Exu, não vou responder, porque Exu mexe com forças que podem interferir no alimento e naqueles que irão se alimentar!", respondeu-me, relembrando, em tom de repreensão, um fato que havia recentemente acontecido conosco. Sua fala reverberava um ensinamento constante na comunidade de que a "palavra é magia" e entender os campos energéticos para fazer um bom uso da palavra "também é mediunidade!". Participação em ipadês e percepção de campos energéticos passaram a ser os meios viáveis no cotidiano comunitário para a construção etnográfica.

No caso em questão, isso implicaria dar uma atenção especial ao que a Morada da Paz chama de mediunidade. A mediunidade designa toda forma de comunicação e relação com o cosmos. Não se trata apenas do processo de incorporação, mas também de intuições e canalizações ${ }^{8}$. As obras literárias ou musicais de grandes nomes, por exemplo, são consideradas frutos de processos mediúnicos. Os sujeitos conseguiram acessar certos registros existentes, assim como certas forças e entidades que habitam o cosmos, e materializá-los neste plano. Dessa forma, o que chamamos de processo criativo é um processo mediúnico de acesso às formas e às informações preexistentes. São os chamados registros akáshicos - termo oriundo do sânscrito - que é um conjunto de informações de tudo o que já aconteceu ou poderia ter acontecido, que acontece ou pode acontecer, que acontecerá ou poderá acontecer. É um mundo dos possíveis, onde nada é determinado ou determinante, mas tudo pode vir a ser.

O trabalho realizado na Morada da Paz com os médiuns é para que o raio de acesso a esses registros e às forças que constituem o mundo se amplifique. Isto acontece através dos chakras, pontos energéticos localizados em diferentes partes do corpo físico. O médium é concebido como um canal 
de comunicação entre os mundos através dos chakras, por onde as entidades e as forças entram. Há uma atenção específica para certos chakras de acordo com as funções desempenhadas pelos sujeitos. Por exemplo, os alabês, aqueles que tocam tambores durante as ritualísticas, receberam a orientação de estar presentes em todas as ritualísticas para trabalhar o chakra das mãos. Na medida em que isso ocorria, acessavam outros planos onde novos toques dos Orixás apareceriam para eles. Contudo, a mediunidade nada tem a ver com o simples desenvolvimento técnico, pois a técnica permite repetir determinados toques, mas não necessariamente acessar outros.

Sem a mediunidade a técnica é repetição. Isto não significa que a mediunidade não implique um aprendizado técnico. É preciso tocar, cada vez mais, para fazer com que o chakra das mãos se expanda e possibilite o acesso a outros toques. O mesmo foi dito para a minha escrita. É preciso escrever para fazer com que os chakras se expandam e outros planos sejam acessados. Por isso, Mãe Preta orientou-me a fazer uma oração, riscar com o dedo na pele de papel uma encruzilhada e acender um incenso antes de qualquer processo de escrita. Se tudo é ritual, a escrita não deixará de ser.

Não desejo com isso fomentar uma autoridade transcendente da escrita, como se a responsabilidade daquilo que escrevo não fosse minha, mas das entidades. Uma compreensão dessas ignoraria o fato, que a Morada da Paz coloca, de que qualquer comunicação com o cosmos é singular e passa também pelos registros de muitas vidas que constituem o próprio sujeito que acessa - registros estes que não se confundem com a memória, pois não são necessariamente conscientes, e que estão diretamente vinculados à perspectiva reencarnacionista da comunidade, ou seja, também não dizem respeito ao inconsciente psicanalítico.

Por isso, mesmo que outra pessoa descrevesse as mesmas questões que eu aqui apresento, sob os mesmos cuidados rituais, muito provavelmente acessaria outras ideias que gerariam outras composições com o cosmos, com as entidades e com a própria comunidade. Aquilo que se acessa, portanto, são virtualidades imanentes da relação estabelecida. O interessante dos acessos, e do modo como a Morada da Paz entende a mediunidade, é que eles acontecem tanto no processo do trabalho de campo, com uma comunicação involuntária e não intencional (Favret-Saada 2005:160), quanto também são partes constituintes do processo de escrita da pesquisa. 


\section{Palavra é magia}

No primeiro sábado de cada mês acontece o Muzunguê, ritual aberto para o público externo de atendimento espiritual, que a cada mês é dedicado a um Orixá específico. O Muzunguê é seguido de um ipadê de reflexão, uma roda de conversa com toda a irmandade, aqueles que participam da corrente, na qual falamos de nossas sensações e percepções sobre o ritual. A cada mês é solicitado para algumas pessoas que escrevam um pequeno texto sobre suas percepções acerca do ritual, que é lido no ipadê de reflexão seguinte. Desde que eu entrei na comunidade, essa tem sido uma atividade constante minha. Escrever e ler para os demais minhas percepções sobre os Muzunguês. As primeiras descrições, que eram as mesmas que eu utilizava em meus diários de campo, eram maçantes e detalhistas, até alguns integrantes da Irmandade me provocarem a escrever um texto "menos enquanto pesquisadora" e "mais enquanto uma iaô-pesquisadora", em que a palavra não se pusesse tanto a serviço da descrição dura - quem faz o quê, como e onde - e mais a serviço das sensações do momento - velocidades, intensidades e os campos energéticos. Como me ensinaram, é possível "conhecer com o arrepio!".

Aceitei, não sem desconfortos, o desafio de escrever sob outras condições. Num primeiro momento, passei a compor dois textos sobre o mesmo acontecimento: um para os meus diários de campo, com a ânsia de que nenhuma informação me escapasse - informações sobre falas, contextos, entre outros aspectos que chamaríamos de 'objetivo', e outro para ler entre minhas irmãs e irmãos, em que as informações sobre o ocorrido não eram tão relevantes, mas sim as percepções mais sutis - as transformações que uma série de acontecimentos em curso produzia sobre meu corpo, como sensações e sentimentos. Com o passar dos meses, percebi que essa separação de escritas não fazia mais sentido. Primeiro, porque eu estava profundamente exausta com o volume textual produzido e o pouco tempo para tal, mas também porque fui tomada por percepções que deslocaram os sentidos de 'objetividade'. Resolvi fazer dos meus próprios diários de campo o lugar onde a iâ̂-pesquisadora se constitui, ou seja, um misto de diário pessoal e diário profissional.

Durante o ipadê de reflexão, a leitura dos meus textos era seguida de certas correções de termos e explicações sobre fatos que eu desconhecia, o que me produzia profundo incômodo. Mas o que queriam com isso, ao me colocarem no papel de descrever os Muzunguês e interferirem no meu relato? Mais ainda, o que queriam ao propor que meu texto fosse menos duro, ao apontar correções de termos durante minha leitura? Da mesma 
forma, o que querem quando desejam acompanhar a escrita do meu projeto, da qualificação e da tese? O desconforto produzido pelo confrontamento da comunidade com meus textos desvelava em mim a ânsia da autoria como um espaço de individualização, herança da modernidade ocidental. Porém, se levo a sério a pesquisa etnográfica a que me propus fazer, e se meus irmãos e irmãs agem e refletem sobre meu próprio fazer etnográfico, preciso levar a sério suas reflexões e ações sobre mim mesma e sobre o meu trabalho. Neste sentido, a relação da antropóloga com a comunidade não termina na feitura do trabalho de campo. A comunidade lê, discute e ocupa a pele de papel, como diz Mãe Preta. E, assim, suas leituras de meus textos e seus efeitos comunitários passaram também a fazer parte do trabalho de campo.

Todo texto escrito que constituiu a feitura da pesquisa foi, primeiro, lido pelas mais velhas da comunidade e avaliado por elas. Aprendi sobre a importância desse primeiro movimento quando, durante a escrita da minha qualificação, enviei aos meus orientadores o arquivo do texto com um anexo - uma espécie de mapa feito por mim - que, segundo as Yas, eu não deveria ter enviado por consistir naquilo que chamam de karó, um dos segredos da comunidade. Além do arrependimento que me acometeu, o fato de eu ter enviado sem o consentimento prévio produziu efeitos na própria Morada da Paz. A exposição de algo que não deveria ser exposto exigiu novas ritualísticas de fortalecimento da segurança energética do território. Seu Sete, em uma determinada situação, apresentou-se no terreiro dizendo que a exposição havia produzido ataques espirituais, permitindo que certas forças, nefastas, encontrassem a comunidade. Disse-me que eu não os senti por conta da minha ingenuidade, mas Yashodhan, Yalasè e mestra da comunidade, sentiu. Era preciso que eu redobrasse os cuidados por conta disso.

Fato é que assim que eu fiz o tal mapa, registrei por foto para anexar na qualificação e o entreguei para a própria comunidade. O que me ocorreu naquele momento foi que a comunidade poderia utilizar o mapa para trabalhar com as crianças sobre espaço e território. Passados alguns dias, Yashodhan me chamou para conversar e expôs a situação: que aquele mapa não poderia ser apresentado para pessoas externas. Questionou o meio que eu usei para enviá-lo aos orientadores e falei que havia sido por e-mail. Disse-me que, então, o mapa estava na internet, seria uma informação obtida por algum servidor, o que a deixou preocupada. Para ela, a internet era um ambiente perigoso, pois toda e qualquer força pode se apropriar do que ali está. O mapa havia sido enviado como anexo e acordamos que eu solicitaria aos orientadores que apagassem aquela versão do arquivo. O mapa produziu consequências não desejadas - uma das formas de ataques espirituais. 
A palavra é perigosa, mas é também poderosa, capaz de produzir efeitos de cura, de acolhimento, de potência. Falar sobre dinheiro para certas demandas comunitárias, num certo contexto, gerou uma série de mal-estares nas pessoas presentes - dores de cabeça, irritações, enjoos - o que precisou da presença de um Exu para limpar o espaço e os sujeitos em questão. Acionar a palavra bruxa e vinculá-la aos poderes das mulheres ancestrais teve por efeito, em outro contexto, uma série de manifestações de entidades, por processos de incorporação, nas pessoas que lá estavam ${ }^{10}$. Com a escrita não é diferente, ela produz efeitos que podem ser danosos ou não. Visto os receios iniciais do que minha escrita poderia vir a ser, quando Yashodhan leu um pequeno esboço da pesquisa que produzi, ainda com ideias iniciais para a qualificação, disse-me que precisava prestar atenção às palavras que eu utilizava na escrita. Assim que ela leu esse esboço de texto, ressaltou o fato de eu usar muito a palavra 'explorar' em meus escritos. 'Explorar o campo', por exemplo. Ressaltou que 'explorar' é uma palavra profundamente vinculada ao colonialismo, carregada de "energias deletérias". Questionou-me, por isso, sobre as forças que eu mobilizava no texto e sobre as intencionalidades às quais eu servia, questão que me desmontou por completo. Eu, que estava tão segura das minhas boas intenções, fui duramente questionada sobre elas.

Como coloca Starhawk em relação ao neopaganismo do qual participa, para a linguagem da magia, uma palavra, uma imagem ou qualquer outro símbolo não tem um significado intelectualmente atribuído, é mais um chamado de atenção: "Olhe, preste atenção nessa coisa" (Starhawk 1988:27). E é dessa forma, sobretudo, que encaro a fala de Yashodhan quando aponta a recorrência do termo 'explorar' em meu texto. Seu questionamento me fez prestar atenção na palavra e, consequentemente, no contexto em que era acionada, o que também me foi alertado por Yashodhan. Seu comentário veio no mesmo momento em que me questionava sobre o recurso textual 'nós', acadêmicos, e elas enquanto o 'outro' que eu mobilizava no texto. Descolar seu comentário desse contexto significativo seria cair num certo substancialismo do termo, ignorar que seu poder existe de acordo com os contextos em que é acionado. E, naquele contexto, do modo como estava sendo acionado, os efeitos que produzia nela o uso da palavra 'explorar', como leitora e pertencente à comunidade, decompunha com as relações da Morada. O que Yashodhan me disse é semelhante ao que Starhawk (1988) nos coloca, um chamado de atenção ao que pode dar ou não poder aos sujeitos da relação ${ }^{11}$.

Talvez o uso do verbo 'explorar' ganhe novos usos e efeitos em diferentes situações, mas naquela em que estávamos ele parecia ser uma ferramenta que corroborava com um Grande Divisor, com o qual as integrantes da 
comunidade já possuem algumas experiências não muito boas ${ }^{12}$. Chamava a minha atenção para o fato de que, se as palavras são magia, era preciso atentar para aquelas que, de alguma forma, dão ou não poder às pessoas com os quais resolvi me engajar e que aceitaram se engajar comigo. Não bastava ser uma iniciada, participar da vida ritual da comunidade e ter boas intenções políticas. Era preciso sentir de outro modo, o que implica também sentir com os 'outros' da Antropologia um "nós" no texto etnográfico, e prestar atenção às imagens e às ideias ali reproduzidas e outras possíveis que "dariam poder" a esse "nós" a ser tecido.

De início, penso que essa relação da Morada com os textos tinha por questão central acompanhar o desenvolvimento de uma nova perspectiva sobre as coisas, em que a antropóloga não mais atuasse por extração e exploração do que é feito na comunidade, mas sim que conseguisse compartilhar percepções e ideias. Porém, essas situações aqui apresentadas e as investidas sobre minhas escritas evidenciaram algo mais profundo, efeitos produzidos pela feitura da pesquisa que não são limitados a uma simples adesão, de estar convencida de suas perspectivas sobre o mundo, e participante em função do compartilhamento de ideias. Partilhar um "nós" implica um sentir compartilhado. Era preciso aprender a "sentir as palavras"13 (Cabnal \& Korol 2017) para a composição de um "nós" e, assim, "sentipensar" de outro modo.

Ao ler meu texto, e incomodada com o 'nós', antropólogas e antropólogos, lugar onde eu me situava e no qual a ela era relegado o lugar de 'outro', Yashodhan contundentemente convidou-me à construção de um "nós" conjunto, em que o "outro" é "a Ciência, a Universidade e os conhecimentos colonialistas". Apontou para as bases colonialistas que historicamente sustentam a Ciência ${ }^{14}$ e para a necessidade de lutar contra isso. Afinal, o colonialismo é uma das facetas produzidas pelas forças das trevas, como diz Mãe Preta. Contudo, e isto talvez seja o mais interessante, esse "outro" não está distante (sobretudo da antropóloga): há sempre o risco da captura por essas forças, o que demanda vigilância e precaução redobrada.

\section{O "nós" intercessor}

Fui orientada pelas mais velhas a ir com outras duas pessoas da comunidade (uma egbomi e uma Ya, ambas mulheres negras) a uma reunião de apoio ao OcupaMinC que ocorria em Porto Alegre, em 2016. Todos os sujeitos presentes foram convidados a se apresentarem e informarem os coletivos que representavam. Ao apresentar a comunidade, 
fiquei profundamente incomodada por me afirmar pertencente a uma comunidade kilombola, como fizeram as mais velhas. Acostumada a trabalhar com coletivos negros, meu esforço é jamais 'falar como' meus interlocutores, respeitando os termos daquilo que chamamos representatividade. Ali, contudo, a situação se inverteu. Não 'falar como' Morada implicou, para elas, um distanciamento inexistente e a manifestação de um perigo eminente. Em uma conversa posterior, tentei argumentar: "Eu não sou negra!". "Você não é a única branca na comunidade e isso é uma percepção errada do que é um kilombo", afirmavam. "Eu não sou uma das fundadoras, como vocês, e desejo respeitar essa história de protagonismo", eu dizia. "Mas você não precisa ser uma Ya para ter axé de fala. Você tem axé de fala como iaô iniciante, dentro da sua própria caminhada", contra-argumentavam.

Essa situação, que para mim foi permeada de desconfortos, conecta-se com a conversa contundente que tive com Yashodhan sobre o texto da qualificação e que abordei parcialmente acima. Yashodhan, após suas duras críticas à relação 'nós e outros' operantes no texto, ainda me questiona: eu, que me apresentei a elas com a intenção de escrever a partir de uma postura ética anticolonial, como eu confronto meus próprios "demônios", ou seja, as "forças deletérias" do colonialismo e do cientificismo que também me habitam, na medida em que havia me colocado como parte de um 'nós' que não as englobava, mas que englobava a Antropologia? Tanto em uma quanto em outra situação a questão que elas me colocavam era a mesma. Os 'outros' da antropóloga são contundentemente questionados, quando me dizem "os 'outros' não somos nós, são eles!".

Naquele momento da conversa com Yashodhan, essa pergunta parecia me inserir em um dilema, tal qual esboçado por Favret-Saada. De um lado, uma antropologia narcisista - e um "nós" que fui convidada a construir e a habitar no texto e que, de início, não parecia produzir nada além de uma constatação identitária, simples adesão - e, de outro, uma clássica antropologia distanciada e um 'nós', enquanto recurso descritivo, que eu confortavelmente fui ensinada a fabricar. Observando o abismo em que eu me encontrava, Yashodhan finalizou nossa angustiante conversa dizendo-me: "aprenda a voar". A investida sobre a própria escrita etnográfica reembaralhou as questões abordadas por mim enquanto antropóloga. 
Vou me eximir de fazer uma retomada sobre como o Grande Divisor tem operado na Ciência ao longo do tempo - produzindo hierarquias e genocídios - para me deter na utilização 'nós e outros' da antropologia como um recurso descritivo, como uma forma de fazer emergir contrastes e, com isso, atuar enquanto intercessor contra a clássica e constante produção de hierarquias entre saberes e vidas ${ }^{15}$. Para Pierre Clastres, a prática etnográfica seria um meio de estabelecer uma relação com aqueles que não são 'nós', para "forjar uma nova linguagem infinitamente mais rica; uma etnologia que, superando essa oposição tão fundamental em torno da qual se edificou e afirmou nossa civilização, se transformaria por sua vez em um novo pensamento [...] que encaminha nossa própria cultura a um pensamento novo" (1968:2). O 'outro' da Antropologia permitiria a ela forjar uma nova linguagem para um pensamento outro sem operar segundo a hierarquização dos saberes, mas situando-se, ela mesma, na própria partilha ${ }^{16}$.

Se há um 'nós', como aquelas e aqueles que desenvolvem práticas científicas oriundas do Ocidente, que nem por isso seja paralisado pela culpa, pelas violências exercidas ao longo dos anos em nome da Ciência, mas mobilizado pela vergonha: "vergonha que consiste em assumir uma responsabilidade em face daquilo ou daqueles sobre quem se escreve, ou melhor, com quem ou diante de quem se escreve" (Goldman 2014b). É bem verdade que herdo da antropologia, ou pelo menos tento, essas noções e o princípio de simetrização entre diferentes saberes, mas parece-me que a colocação feita por Yashodhan de alguma maneira incide nessa relação. Não no sentido de julgá-la ou criticá-la, mas no sentido de fazer com que o "nós" criado pela Morada da Paz e manifestado por Yashodhan funcione como um intercessor, e por isso desestabilize as noções e os funcionamentos em que eu estava bem assentada enquanto antropóloga. Desestabilizar aqui não significa destruir ou desconstruir, mas chacoalhar suas bases para que possamos ver outros elementos antes não percebidos.

Fui obrigada a atentar para o fato de que a busca por uma simetrização de saberes, ainda que tenha implicações políticas interessantes para a Antropologia, de alguma forma não é suficiente para aqueles com os quais eu constituo um "nós". Não é suficiente porque, primeiro, não se propõe a ser. Esse "nós" é fruto de um processo experimental e singular da relação que eu estabeleci com a Morada da Paz. Não caberia à Antropologia supô-lo previamente ao encontro etnográfico, visto o risco de ensurdecimento do que falam nossos interlocutores de campo e da perpetuação de assimetrias. 
Segundo, porque esse "nós" transborda as práticas antropológicas, ainda que incida sobre elas. Se somos 'nós' intercessoras, na medida em que traduzimos para outra linguagem, a antropológica, aquilo que 'nossas' interlocutoras falam, com o intuito de simetrizar esses saberes, fazendo com que - mobilizados pela vergonha que nos chama à responsabilidade - os saberes que aprendemos com esses 'outros' desestabilizem os saberes antropológicos, bem, parece-me dizer Yashodhan, isso não é suficiente. É preciso fabricar um "nós" que seja intercessor conforme ocupe o texto etnográfico, e a ciência antropológica, com vistas à guerra cósmica em curso.

Para além de uma simples constatação identitária, o interessante é o que o "nós" faz fazer, que é atentar para a prática antropológica e engajá-la em uma guerra cósmica em andamento, enquanto prática antropológica. Ele produz algo semelhante ao que Anjos (2017) pontuou em um congresso de Antropologia, cujo impacto foi a total perplexidade e o mutismo daqueles que o assistiam. Comovido por uma imagem recente de um pai negro segurando balas, munições de guerra, que atingiram seu filho e quatro amigos, e ao ler e comentar as apresentações que foram realizadas na mesa em que participou no referido congresso, ele questiona a si e a 'nós' todas e todos: o que importa de fato para essas pessoas com as quais trabalhamos? ${ }^{17}$

É preciso fazer da Antropologia relatório de guerra, diz-nos o autor. Mas, na medida do possível, eu diria, fazer desses relatórios munição para além dos redutos do que é a Antropologia, ainda que atravessando-a com a insistência desse questionamento que não é externo a ela: 'o que de fato importa para essas pessoas?'. A guerra de que nos fala Anjos é uma guerra racial. Anjos, no início de sua fala, aponta como o poder tem se utilizado da "camuflagem" para ter maior incidência sobre os corpos. A mestiçagem é uma de suas camuflagens para atuar nessa guerra contra os corpos negros. Mas ele faz um adendo sobre essa camuflagem. O que nos diz Anjos é que o poderoso feitiço da mestiçagem colonial não tem nada por trás da pele como camuflagem racial.

A guerra de que nos fala a Morada é uma guerra cósmica que engendra essa guerra racial e tantas outras. Sugiro, então, tendo em vista a guerra cósmica em curso na qual eu fabrico um "nós" com a Morada no texto etnográfico, que o 'nós' que eu herdo da antropologia exista somente como camuflagem. Se eu entendi o que Anjos quis dizer, acredito que nesse caso haja algo por trás que é, na verdade, outra pele. Pois se trata aqui, sobretudo, de peles e não de essências. Uma outra pele que nos impede de esquecer... O contrafeitiço que "nos" cabe nessa guerra cósmica é, principalmente, não esquecer. 


\section{Contra a amnésia}

Ao vivenciar a relação "nós e outros", fui levada a sentir de modo mais contundente as questões que as feministas há tempos têm colocado para as ciências em geral como uma outra forma de organizar o conhecimento, entendendo-o como localizado ${ }^{18}$. Tomo parcialmente emprestados os contrastes desenhados por Strathern (2006), quando contrapõe as produções da ciência social às produções feministas para realizar uma crítica ao conceito de sociedade, com o intuito de extrair disto algumas comparações. Para ela, o conhecimento feminista e o conhecimento da ciência social, ainda que compartilhem de uma estrutura familiar e de sua origem dentro do pensamento ocidental, carregam profundas diferenças. Primeiro, o objetivo da pesquisa feminista não é uma descrição detalhada, "mas expor os interesses que informam a própria atividade descritiva". Assim, tem menos interesse na relatividade dos pontos de vista constituintes da "sociedade" ou "cultura", ferramentas clássicas da Antropologia. Ao contrário, "busca todas as maneiras pelas quais, para os mundos que conhecemos, faria diferença reconhecer tanto as perspectivas das mulheres como as dos homens" (Strathern 2006:53). Para a intelectual feminista, por oposição a outros intelectuais, o que interessa é a promoção dos interesses das mulheres. Importam menos os interesses internos à construção do conhecimento, a descrição adequada, mas sim os externos - aqueles que provêm do mundo social do qual também fazem parte.

Enquanto as feministas compartilham a ideia de que todas as mulheres ocupam posições comparáveis, em suas práticas intelectuais sustentam uma constante diferenciação de posições que são criadas reciprocamente dependentes, afirmando-se umas em relação às outras. Para elaborar um ponto de vista a partir do feminismo radical, é preciso evocar o feminismo marxista e liberal para construir as bases sobre as quais se fala e vice-versa. Dessa forma, nenhum ponto de vista é individualmente autorreprodutivo e o feminismo é antes plural que holístico. Ele é um campo de múltiplas perspectivas, onde uma evoca todas as outras para se constituir e se diferenciar. Contudo, diz-nos a autora, a cada perspectiva constituinte dessa pluralidade, existe uma perspectiva dual, um outro para o qual o pensamento feminista se posiciona: o patriarcado.

Existe uma finalidade específica no feminismo: ele visa a uma ação prática - conhecer para transformar a situação das mulheres. Se para a Antropologia o interesse está na descrição dos diferentes pontos de vista que constituem a sociedade, para as antropólogas feministas são os vários pontos de vista de mulheres que refletem as múltiplas experiências da 
condição feminina. Enquanto a pluralidade da primeira está no 'outro' com o qual estuda (em que gênero é uma abordagem possível entre outras em face da sociedade enquanto ente totalizante), a pluralidade da segunda está no 'nós' do qual a observadora faz parte. O que há são diferentes modulações de interioridade e exterioridade. A autora segue em suas reflexões, mas a mim interessa principalmente essa relação que o feminismo traz de sua intensa pluralidade interna.

As feministas, quando afirmam um "nós", o fazem em função daquilo a que desejam sobretudo se opor: o patriarcado - a dualidade da qual fala Strathern (2006). Isto não implica negar a complexidade e a pluralidade inerente desse "nós". Da mesma forma que Strathern recupera um jogo de posicionalidades intrínseco ao feminismo, percebi que o risco de uma falsa representatividade me obrigava a fazer o mesmo em relação a este "nós" e suas diferenciações intrínsecas. Habitar o "nós" obrigou-me sobretudo a atentar para a questão da posicionalidade e da audiência.

Primeiro, é importante salientar que, assim como as feministas, a Morada da Paz também estabelece uma relação dual entre as forças com as quais se alia e outras que combate - é nessa relação que surge o "nós e os outros" - que são as "forças das trevas" e tudo aquilo que engendra e atua no mundo. Também estabelece uma relação com o conhecimento que visa à transformação do mundo que habita ${ }^{19}$. Quando Yashodhan me provoca a escrever como um "nós", ela me convida a habitar um outro lugar dessa relação que, para mim, não foi nada confortável, tendo em vista esta clássica configuração de poder que atravessa e constitui meu corpo (branca, acadêmica, classe média). Foi preciso "desacelerar o pensamento" antes de aceitar habitar esse espaço de forma irresponsável. Habitar este "nós" é habitar suas complexidades e diferenciações internas, que são evocadas continuamente, de constante feitura das posicionalidades.

Neste "nós" existe uma diferenciação entre os humanos e os não humanos, ainda que estes últimos atuem constantemente sobre os primeiros e vice-versa. Quero dizer com isso que o "nós" criado pela Morada implica tanto a participação de humanos quanto a de uma série de entidades com as quais os propósitos existenciais da própria comunidade são criados: Orixás, caboclos, pretos-velhos, e outros seres que habitam o cosmos. O fato de ser reconhecida e de me reconhecer como mulher me permitia estar na maior parte dos espaços - rodas de conversas ou determinados rituais exclusivos - e habitar de forma mais 'confortável' um "nós" compartilhado, mostrando ser evidente que minha experiência corporificada era entrecortada por outros níveis de diferenciações, o que torna parcial esse primeiro compartilhamento. Uma delas, e talvez a mais contundente, é a racial. 
Ainda que haja outras pessoas brancas na comunidade e mesmo que Yashodhan tenha argumentado que um kilombo é um espaço da diversidade, não raro essas diferenciações se faziam presentes e evidenciavam a branquitude enquanto uma estrutura social de poder, na qual o meu corpo é um signo participante e posicionado.

Certa manhã, Yashodhan rebateu um comentário de Yabasè que dizia que eu e outra iaô branca éramos "negras por dentro". Yashodhan disse que não concordava com esta expressão, pois se concordamos com a existência de brancos com "alma negra", também aceitamos a existência de negros com "alma branca". E, segundo ela, esta concepção daria razão ao racismo, na qual se valoriza o negro de "alma branca". O que há são brancos e negros e, assim como há negros que são capitães do mato, há brancos sensíveis às resistências negras. A questão é que as relações raciais não são ali neutralizadas ou ignoradas. Elas emergem das experiências vividas, das memórias, dos espaços de circulação, das possibilidades financeiras, dos resquícios de uma sociedade escravocrata, e demarcam continuamente diferentes posicionalidades que são investidas de poder.

Ao sair de um Muzunguê, ou seja, de um atendimento espiritual que acontece aos sábados, comentei com um grupo de egbomis (irmãs mais velhas) que tinha percebido muitos parentes delas no atendimento. Logo uma das irmãs disse-me, impaciente: "Não! É porque pra branco, negro é tudo igual, né!". Na hora me muni das inúmeras justificativas para o meu comentário. No fim, a conversa derivou para outros lados, mas aqueles segundos produziram em mim um forte mal-estar pela revelação de alguns dos muitos "demônios", nas palavras de Yashodhan, constituintes da branquitude que estavam ali presentes e que foram nomeados com a fala impaciente desta irmã.

A branquitude operante através do meu corpo era denunciada ou também desmontada pela invisibilidade. Lembro-me aqui de uma situação interessantíssima que ocorreu durante uma reunião do Grupo de Estudos Afro (GeAfro) que acontece na UFRGS. Uma das participantes, mulher negra, havia estado junto com a mãe em alguma das atividades da Morada da Paz. Quando conversamos, falou com empolgação da sua vivência na comunidade. $\mathrm{Eu}$, que estive em muitos dos momentos narrados por ela, comentei que me lembrava dela e de sua mãe. Ela, na maior espontaneidade e indiferença, disse não lembrar de mim. Na indiferença ou na impaciência, nomeiam a norma e a desestabilizam. Dessa forma, obrigam-me à posicionalidade de uma mulher branca em meio às mulheres negras com as quais fabrico um "nós", que cada vez mais se mostra um recurso nada fixo, nem estável, nem totalizante. 
Se retomo esses fatos aqui, não é para adotar a culpa por um signo que me compromete, independente da minha boa vontade. Mas, antes, pela vergonha de ser branca. Primo Levi, a partir da reflexão sobre a "vergonha de ser um Homem", refere-se aos fatos aterrorizantes que constituíram o Holocausto, e Deleuze, desde as colocações do Primo Levi, nos diz que certamente não haveria razão para pensarmos que somos todos responsáveis pelo nazismo, mas somos, de alguma forma, manchados por ele, mesmo os sobreviventes que tiveram que fazer concessões. "Vergonha por ter havido homens para serem nazistas, vergonha de não ter podido ou sabido impedi-lo, vergonha de ter feito concessões, é tudo o que Primo Levi chama de 'zona cinza'" (Deleuze 2010:217). O mesmo podemos pensar em relação à estrutura racial em que vivemos, fruto de uma relação tão aterrorizante e perversa quanto, ou mais, a que aconteceu no Holocausto, que foi o processo de escravidão dos povos africanos trazidos às Américas ${ }^{20}$.

Para além da diferença racial, outras diferenciações aparecem. Como escrever a partir de um "nós" se o tempo de vivência que eu tinha na comunidade era tão pequeno? Foi quando Elemojò me explicou sobre a hierarquia circular, composta por Iaôs, Egbomis e Yas e Baba. Eu falaria como "nós" do lugar que eu ocupo como uma iaô iniciando uma trajetória espiritual, com as responsabilidades de uma iaô iniciante. Minha posição, segundo ela, não é nem melhor e nem pior que a posição de uma Ya, visto que só existem Yas porque existem iaôs e vice-versa. Há uma relação de dependência mútua que nem por isso constitui uma totalidade de perspectiva.

Mas não apenas o tempo de iniciação aparecia como um corte diferenciador, também o lugar que eu ocupava como demoradora, aquela que não mora na comunidade. Aliás, desde o momento em que iniciei minha relação com a comunidade, as pessoas designadas como demoradoras e moradoras variaram bastante. Até que, em início de 2018, após um rompimento ocorrido entre as mais velhas e sete demoradoras, Mãe Preta orientou para que não houvesse mais demoradores na comunidade e os novos iniciados passariam a morar no território. Eu, que havia restado como única demoradora, reelaborei a relação com a comunidade a partir da noção de aliança, termo que foi trazido por Yashodhan e que implica uma relação de troca e cuidado mútuo, em que existe, nas palavras de Yashodhan, "uma matéria energética da gratidão que alimenta a relação".

Minha posição de iaô mostrava-se instável, mas também a de pesquisadora, visto que a relação 'pesquisadora' e 'nativos' compõe esse jogo de posicionalidades. Primeiro, por eu ter entrado em um processo de iniciação, o que de alguma forma me colocava em um lugar de 'nativa'. Se em alguns momentos parte das pessoas esquecia que eu também era 
'pesquisadora' - e eu recebia orientações, tinha compromissos e participava ativamente nos ipadês, rodas de conversa, como qualquer outra demoradora - em outros, essa diferença era consideravelmente marcada - Mãe Preta não tardava em perguntar, quando manifestada, sobre meus escrevinhados.

Também porque muitas das mais velhas, e das mais novas, desenvolveram suas teses, dissertações e trabalhos de conclusão sobre a comunidade, portanto, são tão 'pesquisadoras' quanto eu. Porém, se isso é verdade, também é verdade que não significa que eu seja 'nativa' como elas, nem que elas sejam 'pesquisadoras' como eu. Não porque sejamos mais ou menos 'nativas' ou 'pesquisadoras', mas simplesmente porque cada uma que ocupou ou ocupa o lugar de pesquisadora se conecta com aspectos singulares - sejam aspectos da comunidade, sejam leituras e métodos de pesquisa oriundos da Universidade - e, portanto, acessa diferentes registros, se conecta com diferentes dimensões e forças para a composição do que será escrito em suas pesquisas.

Da mesma forma, ocupam-se lugares diferentes enquanto 'nativas' - há as Yas e Baba, as egbomis, as iaôs, os moradores, os demoradores, enfim, uma série de cortes operados nos cotidianos dos sujeitos que permitem distintas experiências, impossíveis de serem hierarquizadas em maior ou menor acesso à 'verdade' do que 'é' a Morada. Se tomarmos a organização operante na comunidade de hierarquia circular, isso se torna ainda mais impensável. Ali a hierarquia é móvel, de acordo com os termos da relação e as questões que se apresentam, assim como o panteão dos Orixás com o qual a Morada se constitui. Oxalá, por mais alto que esteja na hierarquia do panteão africano, não pode atuar nos campos energéticos em que atua Exu. O que faz com que Exu esteja no alto da hierarquia em determinadas situações. E vice-versa. O mesmo poderíamos pensar para a relação entre 'pesquisadoras' e 'nativas'.

Assim como as teóricas feministas evocam a pluralidade de posições que constituem o feminismo - nunca supondo uma totalidade - evoco também essa pluralidade de posições que constituem esse "nós" do qual participo e do qual não posso jamais me esquecer. Apresentar uma série de posicionalidades em jogo nos ajuda a sair da base identitária e fazer do "nós" um experimento do pensamento.

O "nós" não surgiu de uma construção prévia à relação, porque se trata sobretudo de uma composição de forças que deriva um bom encontro. Existem movimentos, elementos que atravessam a Morada da Paz e que não atravessaram este texto, assim como há movimentos, elementos que me atravessam e que também não o atravessaram. Mas há aqueles que emanam da Morada e outros que emanam de mim, sendo a prática antropológica um 
dos vetores que, de alguma forma, confluíram na produção desse "nós". Resta prolongá-lo, no sentido de existir para além da Antropologia, mas também prolongá-lo no interior da própria Antropologia. Fazer com que a guerra cósmica exista na Antropologia não apenas como algo a ser descrito, mas como algo constituinte deste fazer etnográfico.

Por conta disso, acredito que esse "nós" seja sobretudo uma luta contra a amnésia, assim como Stengers e Despret (2014) colocaram em relação ao grito dado por Virgínia Woolf, quando ela se negou a assinar junto com os homens um manifesto pela liberdade intelectual, que tinha por intuito evitar uma ameaça de guerra - a investida nazista que estava por acontecer - num contexto em que mulheres não podiam frequentar Universidades e nem desenvolver seus estudos tal como os homens de seu tempo. O tal manifesto era recheado de boas intenções de pessoas que não queriam a guerra, mas também que não permitiam comprometer os seus valores. A partir disso, Woolf negou corroborar com aquela situação, ver aquilo que mais prezava ser mobilizado por seus inimigos, e produziu um grito: "não em nosso nome!", não em nome das "filhas e irmãs dos homens instruídos". E, com esse grito, interrompe qualquer tentativa de amnésia, de esquecimento, sobre as desigualdades e os silenciamentos que pesavam sobre as mulheres de seu tempo e daquelas que vieram antes.

Sinto que o "nós" elaborado pela Morada da Paz e o grito duro que ecoou naquela conversa em que Yashodhan me empurrava para o abismo e dizia-me "aprenda a voar" carregam um tanto dessa luta contra o esquecimento, que provoca a pensar contra o consenso, na medida em que desestabiliza as bases tão assentadas em que eu estava. Um modo de criar uma memória fonte de resistência. As ritualísticas que fui ensinada a viver constituem também meios de lembrar, de reviver, retroalimentar o "nós" que tecemos. O "nós" do qual participo lembra-me dos riscos do esquecimento, dos perigos constantes de que o "nós" seja desfeito e, principalmente, das lutas que devem ser travadas.

"Não em nosso nome" poderia ser, também, uma fala de Yashodhan quando defrontada com meu texto inicial e a operação descritiva 'nós e outros', recheado de boas intenções políticas. O "nós" como todos os 'outros' do poder colonial e capitalista que, em nome deles, foram e são dizimados, silenciados, torturados. Como se me dissesse: não, não compactuarei com esse 'nós e outros' na medida em que você não leva suficientemente a sério em seu texto a guerra em que estamos implicadas e na qual você está mergulhada até o último fio de cabelo. Você não leva suficientemente a sério nossa memória ancestral! Ancestral porque para a elaboração desse "nós" muitos resistiram contra as forças destrutivas que produzem o colonialismo e 
o capitalismo que você diz querer combater! Um "nós" que não trata apenas dos humanos que constituem a Morada, ainda que os englobe, mas todos os outros - ancestralidades, entidades, seres que constituem o cosmos e com os quais a Morada da Paz compõe a vida.

O "nós" que fui chamada a habitar é um convite para fazer prolongar no texto etnográfico e na Antropologia essa memória ancestral que já não é apenas delas, das mais velhas. Na medida em que me deram a responsabilidade em participar desse "nós", e assim eu aceitei, essa memória ancestral passa a ser também minha, mesmo que de outra forma. Da mesma maneira que a Morada recupera elementos de outros tempos e contextos e os transforma em função do presente, devo recuperar elementos desenvolvidos no contexto em que a Morada existe e transformá-los em razão do que é a Antropologia. Portanto, retomando uma colocação de Stengers e Despret (2014), recuperar a transmissão dessa memória ancestral "inclui saber que ser fiel à pergunta que alguém transmite requer sua transformação". Ser fiel às questões que permeiam a existência da Morada da Paz nesta guerra cósmica e tomá-las através da Antropologia é escavar outras trincheiras.

Lembro Favret-Saada. Ela aprendeu que para a feitiçaria em Bocage a palavra produz efeitos no mundo e, por isso mesmo, funciona a partir de um jogo de posicionalidades. Não se poderia falar em feitiçaria sem ter sido afetado por ela, assim como, para a Morada da Paz, não se poderia falar na guerra cósmica em curso, que constitui o propósito existencial da Morada, sem estar engajado nela. Mas aqui há uma diferença que sinto ser importante. A autora foi afetada pelas mesmas forças que afetam seus interlocutores em campo, e sua experiência produziu efeitos sobre a própria prática antropológica. No caso que vivo com a Morada, a participação constante das mais velhas no próprio texto antropológico demonstrava que a ideia de que "a palavra é magia" não apenas afeta o encontro etnográfico, mas também a própria escrita etnográfica, é, para a Morada da Paz, magia. E, se não é apenas isso, pois é uma prática antropológica que coloca problemas de uma dada ordem, através da disciplina da qual 'nós' participamos, é também magia. E a insistência do "nós", elaborado por Yashodhan, parece não me permitir esquecer disso. Bem, a questão aqui não é se devo crer ou não, enquanto antropóloga, no que os 'outros' da antropóloga creem, mas sentir o convite para participar de um "nós" e engajar-me em um experimento do pensamento da própria etnografia enquanto magia. 


\section{Sentipensar nós devemos}

"Pensar nós devemos" é um grito insistente de Virginia Woolf reativada pelas filósofas Stengers e Despret (2014) em outro contexto. "Pensar nós devemos" de Woolf foi um chamado às mulheres para que tivessem prudência em aceitar adentrar espaços, como a Universidade, que foram negados a elas e às que vieram antes delas. Mais do que isso, era um convite a negar permanecer nesses espaços, em nome de uma memória ancestral. As filósofas reconhecem-se, então, como as "filhas infiéis de Virgínia Woolf", por serem aquelas que entraram na Universidade e decidiram nela permanecer, mas, nessas condições, não deixam de herdar ${ }^{21}$ de Woolf a insistência de uma memória ancestral.

Quando Stengers e Despret (2014) assumem o compromisso de Woolf é sobretudo para fazê-lo ecoar, reverberar de outra forma, nesse contexto em que escrevem como aquelas que adentraram e permaneceram na Universidade. E destacam que fazer jus a este compromisso é opor-se à reatualização das forças que negam a presença de certos sujeitos no espaço universitário sob a argumentação universal e meritocrática do produtivismo. É também explicitar o que se esconde por trás da "democratização" moderna, que nada mais é do que a aceitação daqueles que foram historicamente excluídos desses espaços na exata medida em que negam que esses sujeitos afetem e reestruturem suas bases. Novamente a tolerância: aceitamos vocês, desde que não façam barulho, desde que não queiram alterar a ordem das coisas.

Pois bem, ninguém melhor do que as mais velhas da comunidade Morada da Paz para saber disso. Mulheres negras e homem negro que passaram e passam pela graduação, mestrado, doutorado e pós-doutorado, mas que resolveram ouvir os conselhos de Mãe Preta sobre a Universidade e disseram a si mesmas: esse lugar é perverso demais, muito mobilizado por competitividade e egoísmos, e eu corro riscos de me perder de mim mesma. Daqui podemos "roubar"22 o que nos serve, mas jamais permanecer. Podemos produzir incômodos às estruturas bem estabelecidas, até mesmo fomentar nossos aliados que ali estão para que causem barulhos, mas apostamos que a transformação do mundo, como desejamos viver, não vem propriamente das estruturas universitárias.

Aqui é preciso alguns cuidados, desacelerar o pensamento e engajar-se com a Morada numa tentativa de pensar contra o consenso. Não me parece, pelos anos em que convivemos, que seja o caso de questionar as contribuições que as práticas científicas, nos seus sentidos experimentais e especulativos, têm possibilitado. Se assim o fosse, negariam a possibilidade 
dessa composição comigo, enquanto antropóloga, assim como com outros cientistas e trabalhadores da educação nas Universidades que frequentam a comunidade e desenvolvem projetos em alianças e parcerias. Contudo, essas relações são extremamente cuidadosas, porque sabem, também, o modo com que a Ciência ocidental, e uma de suas principais residências, a Universidade, construiu sua hegemonia, investida da herança iluminista, da racionalidade e da objetividade, e a serviço de validações etnocidas e epistemicidas embaladas pelas noções de progresso e desenvolvimento.

Pensar contra o consenso, a partir das provocações de Yashodhan, não é sustentar que as práticas científicas não serviriam mais para elaborar respostas comprometidas e responsáveis - como parecem sugerir aqueles que fomentam a precarização e a desqualificação destas; ao mesmo tempo, não é corroborar com a defesa irrestrita da Ciência, e suas demasiadas certezas - como parecem desejar alguns cientistas o retorno a um passado. O que Yashodhan faz, com a destreza da mestra que é, é objetar tais práticas e exigir participar de tais formulações, pois derivam disto consequências em relação à guerra cósmica que sem a sua contestação não seriam consideradas na ordem consensual da descrição etnográfica, todavia têm efeitos na Morada da Paz e no modo como experienciam o mundo. E, sobretudo, podem fazer com que a Antropologia, enquanto prática científica, também entre em um potente devir.

Entre 2017 e 2018, com as notícias de cortes de verbas do CNPq e Capes, Yashodhan disse-me que entendia a necessidade de protestar contra essa situação e percebia com pesar o desmantelamento da Universidade. Por outro lado, sentia que a lógica que sustenta a Universidade, tal qual ela se apresenta, já estaria dada ao fracasso. Como se reatualizasse Woolf, agora num tom de questionamento, pensativa: lutar pela manutenção dessa lógica universitária? Em nosso nome? Aquelas e aqueles que foram historicamente excluídos e, muito recentemente, pelas Ações Afirmativas e outras políticas de democratização, participam desse mundo, muitas vezes em condições precárias, sem participar da formulação das regras do jogo? Em nosso nome?

As questões que emergem sobre a Universidade possibilitam aproximações entre as filósofas Stengers e Despret (2014) e as mais velhas e fundadoras da Morada da Paz. Mas suas apostas foram diferentes. As primeiras resolveram permanecer na Universidade e pensá-la como um espaço de resistência. Resistência ao produtivismo, resistência aos espaços bem constituídos do que seria considerado "a verdadeira filosofia", resistência ao papel de juízas sobre os outros e resistência a participarem das polêmicas que a herança da filosofia lhes coloca, preferindo antes a possibilidade de rir e pensar junto com outros que não os já instituídos 
pela disciplina na qual participam. As segundas viram em outros espaços a possibilidade de resistência, pois demandavam elementos vitais para as suas vidas que a Universidade não seria capaz de possibilitar, aceitar, nem mesmo tolerar. Preferiram resistir, rir e pensar junto com outros na criação coletiva da Comunidade Kilombola Morada da Paz.

Não se trata aqui de julgar uma ou outra postura, ou dizer qual seria a melhor ou a mais acertada. A questão que me cabe fazer, como alguém que escolheu permanecer na Universidade, é: como prolongar o "nós" da Morada da Paz para ser capaz de produzir algum barulho dentro dessa estrutura de que eu faço parte enquanto antropóloga? Recebi uma série de orientações de Mãe Preta em relação à feitura da pesquisa e do que fazer com ela depois de finalizada. Uma dessas orientações foi para que Yashodhan estivesse em minha banca de defesa de doutorado, "enquanto Yashodhan". Não enquanto pós-doutora, tal como é, mas enquanto mestra e fundadora da comunidade Morada da Paz. Isto provocou questionamentos, indagações, reticências minhas e de outras pessoas da Universidade com as quais eu dividi esta questão.

Dentre eles, houve quem pautasse, novamente, a separação 'nós' e 'outros'. Obviamente, não no sentido de supor a hierarquização de saberes, mas para demarcar o que é a Antropologia, o seu modo de elaborar e pôr problemas, que seriam diferentes dos problemas que, talvez, Yashodhan levantasse enquanto Yashodhan. O "nós" provocado pela Morada da Paz novamente incide sobre a relação 'nós e outros'. Não parece querer ferir ou derrubar o que é e o que constitui a Antropologia, mas também não parece comprometido com a manutenção dela por princípio e com os limites que cria para sua autodefinição. Porém, se o que 'nos' cabe, como antropólogas e antropólogos, é sobretudo sentir e pensar com 'outros', precisamos levar em consideração que esses 'outros' estão na e pensam a Universidade e suas práticas científicas. Que a desestabilização dos 'nossos' próprios saberes, inclusive dos problemas que a Antropologia formula para si, sirva à desestabilização das 'nossas' próprias estruturas de produção de conhecimento, sem precisarmos supor heroísmos ou julgamentos de quem quer que seja. Afinal, isso só pode ocorrer de modo experimental, sem sabermos quais serão suas consequências - para a Antropologia, para a Universidade ou para os ditos 'outros' da Antropologia.

Desde que iniciei minha relação com a Morada, Mãe Preta diz que a Universidade, do jeito como está, já acabou e não vai mais existir. Para Mãe Preta, seria preciso criar outras formas de produção e disseminação do conhecimento e das práticas científicas junto com os povos e seus saberes. 
Eu tomo essa fala de Mãe Preta não como um presságio fatalista, mas como um convite a sentir de outra forma. Sentir um fim consumado e com isso exercitar nossa capacidade de sonhar, como diria a Morada da Paz, ou de "fabular"23, como diria Stengers e Despret, outras possibilidades. Não muito diferente disso fizeram as moradoras e os moradores da comunidade Morada da Paz quando as entidades disseram a elas que o fim do mundo já estava posto e seria necessário criar outro. Juntas com outros (humanos e não humanos) sonharam a possibilidade de outro mundo e criaram a comunidade Morada da Paz. Eu tomo a fala de Mãe Preta como um convite à criação, sobretudo nestes tempos tão tenebrosos. Para isso, não é preciso aderir à Morada ou à Mãe Preta, mas permitir-se sentir de outra forma para poder pensar de outro modo. Como disse Yashodhan após a leitura deste artigo, a palavra que está em jogo para "nós" é reconstrução. Imaginar, 'nós' que estamos nas Universidades, outras possibilidades de existência.

Recebido em 05 de setembro de 2019

Aprovado em 19 de maio de 2020

Luiza Dias Flores

Professora do Departamento de Antropologia da Universidade Federal do Amazonas. Tem experiência de pesquisa com antropologia das populações afro-brasileiras, com principal interesse nas cosmopolíticas, modos de conhecimento e teorias etnográficas da mistura.

https://orcid.org/0000-0002-6809-4803

E-mail: luizaflores@ufam.edu.br 


\section{Notas}

1 A pedido da comunidade, assino também como Folaiyan, tal como sou reconhecida. As grafias do texto seguem a seguinte ordenação. Itálico marca as expressões e os conceitos da própria comunidade. Utilizo aspas duplas e o itálico para falas da própria comunidade. Aspas duplas marcam conceitos, expressões e textos das/os autoras/es com os quais dialogo. Aspas simples são utilizadas para expressões que desejo ressaltar.

2 Contracolonizadora porque foi sobretudo sobre 'confrontar os saberes hegemônicos' o início desta composição que teci com a Morada. O conceito de contracolonização eu retomo de Santos (2015) de seu livro, mas principalmente a partir de duas falas que realizou no Programa de Pós-graduação em Antropologia do Museu Nacional/UFRJ, onde negou o termo descolonização para os povos que sofreram a investida colonial, dizendo que para 'des'-colonizar é preciso saber colonizar, para então desfazê-la. Negou o saber colonizar como desfazer algo que foi feito e produz suas consequências. Ele cunha, portanto, o termo contracolonização como uma forma de confrontar e desestabilizar o colonialismo, mesmo quando este se apresenta em situações não tão instituídas. Percebo a ação da Morada sobre o convite que fiz a ela dessa forma, permitindo que houvesse entre nós uma composição possível.

3 Nomeiam-se kilombolas para recuperar o sentido bantu do termo: fortaleza, união. Diferenciam kilombola de quilombola. Este último seria a "língua do colonizador" que as tornam remanescentes de antigos quilombos. Afirmam-se sobreviventes: não aquelas que restaram, mas aquelas que resistiram e sobreviveram às investidas coloniais. Entendo o kilombo como uma modulação do que Nascimento (1980) chamou quilombismo: "ideia-força, energia que inspira modelos de organização dinâmica desde o século XV" (1980:256). O quilombismo, para o autor, é um movimento de inúmeras práticas associativas, ilegais ou toleradas pelo poder colonial e estatal que sustentavam e sustentam a necessidade de assegurar a "existência do ser" da população negra, resgatando a dignidade e a liberdade através da organização de uma sociedade livre.

4 Iaô, do modo como fui ensinada, trata-se daquela que aceitou seguir o caminho espiritual de reverência aos Orixás e aos ensinamentos obtidos e vivenciados na comunidade.

5 "A espiritualidade não tem lado", dizem. Trata-se de um conjunto de forças que habita o cosmos, algumas sabendo-se nomear; de outras sabem apenas que existem; de outras ainda nem imaginam a existência. Guerra cósmica é um dos conceitos centrais que trabalho em minha tese. Trata-se de uma guerra entre forças - não entre sujeitos, nem mesmo entre estruturas sociais, mas forças que atravessam, afetam, engendram, produzem sujeitos e coisas, e tudo aquilo que estaria, para nós, no âmbito da 'política'.

6 Yas designa o conjunto de mais velhas e fundadoras da comunidade, compostas por quatro mulheres, Yas (mães), e por um homem, reconhecido como Baba (pai). 
7 Conforme Deleuze (2002:28-9): "Bom e mau têm pois primeiro sentido, objetivo, mas relativo e parcial: o que convém à nossa natureza e o que não convém. E, em consequência, bom e mau têm um segundo sentido, subjetivo e modal, qualificando dois tipos, dois modos de existência do homem: será dito bom (ou livre, ou razoável, ou forte) aquele que se esforça, tanto quanto pode, por organizar os encontros, por se unir ao que convém à sua natureza, por compor a sua relação com relações combináveis e, por esse meio, aumentar sua potência. Pois a bondade tem a ver com o dinamismo, a potência e a composição de potências. Dir-se-á mau, ou escravo, ou fraco, ou insensato, aquele que vive ao acaso dos encontros, que se contenta em sofrer as consequências, pronto a gemer e a acusar toda vez que o efeito sofrido se mostra contrário e se revela a sua própria impotência".

8 Há três formas sabidas de manifestação da mediunidade: incorporação (quando o corpo do médium serve de canal para a manifestação da entidade), canalização (quando o médium acessa via produção escrita, musical ou pictórica alguma mensagem espiritual) e intuição (quando o médium se comunica com o cosmos de modo mais sutil, sente orientações dadas).

9 O conceito de ocupar é o fio condutor da pesquisa que realizei com a Morada da Paz (Flores 2018b). Ocupar é retomado pela comunidade como uma estratégia em face da guerra cósmica em curso. Ocupar surge na encruzilhada de duas outras noções: a dos movimentos sociais, como um ato político de questionar a ordem dada pela lógica da propriedade e dos indivíduos proprietários e criar novas formas de vida e de imaginação política; a do Batuque, religião de culto aos Orixás presente no RS, na qual é atribuído ao Orixá que incorpora no médium uma força potente que ocupa o corpo de seu cavalo. A Morada da Paz entende ocupar como o cruzamento destas duas concepções.

10 Trago essa situação de forma mais detalhada em outro artigo para discutir o conceito de feminino na comunidade Morada da Paz (Flores 2018a).

11 Segundo Starhawk: O idioma distribui poder. A palavra miserável é uma palavra que posso usar sobre mim mesma; me dá poder para nomear e, assim, nomear meus próprios sentimentos. Note que é um adjetivo. Descreve algo que estou fazendo (sentindo). É relacional. Depressão anaclítica é um termo usado por profissionais quando falam de outros e não deles próprios. Pode ser útil. Transmite, talvez, uma categoria diagnóstica mais precisa, aponta para uma história implícita mais completa do que miserável. Mas é útil para profissionais, não para mim. Não me dá nenhum poder para me conectar com meus sentimentos porque transforma meu sentimento em um objeto, uma condição, algo que tenho e, portanto, sou distanciada, alienada de como me distancio daqueles que usam o termo sobre mim (Starhawk 1988:24, tradução minha).

12 O Grande Divisor persegue a ciência há tempos e se institui na Antropologia desde o Evolucionismo. Trata-se do jogo em que tanto nós, cientistas, quanto nossos interlocutores sabemos das suas consequências assimétricas: de um lado, o melhor lugar - do sujeito de conhecimento, da Ciência, da Modernidade e do Real - e, de outro, o pior - do objeto de conhecimento, da crença, do atraso e do falso (Ver FavretSaada 2005; Goldman \& Lima 1999). 
13 "Sentir as palavras" é uma colocação trazida, em diálogo com Cláudia Korol, por Lorena Cabnal, feminista comunitária Maya-Xinka da Guatemala, que implica um ato de descolonização em face da palavra dita e escrita. Entendo sua colocação não como corroborando com uma percepção ocidental sustentada nos dualismos homem x mulher, civilizado x primitivo, ambos tratados como equivalentes a outra clássica dualidade, razão x emoção, mas sim como a apresentação de um outro regime de verdade que rompe com essas atribuições ocidentais. Ela nos diz: "Eu queria convidá-las para que sintam minha palavra, que escutem minha palavra sentindo-a. Se vão racionalizar, vamos pôr poder e mais poder à lógica racional, como um dos poderes colonizados pela construção que foi internalizada profundamente em nossos corpos. Convido-as a que não racionalizem o que vou compartilhar. Só sintam minha palavra que não é de minha individualidade, mas vem de vários corpos de mulheres indignadas, com as quais temos tecido essa proposta. [...] Sentir a palavra é um ato de descolonização da racionalidade que foi imposta, como uma maneira positiva de interpretar uma realidade. Somos corpos sentipensantes. Com isso rebatemos o que a filosofia ocidental nos ensinou como 'penso, logo existo'" (Korol 2017:298, tradução minha). Starhawk (e Isabelle Stengers através de Starhawk) também recupera uma percepção de sentir em oposição à adesão quando se referem à Deusa. Como nos diz Stengers no posfácio escrito no livro de Starhawk, a Deusa não quer reconhecimento ou adoração, pois não implica adesão, mas sentir. Esse sentir pode provocar as mais diversas experiências nas pessoas e, com isso, fazer com que pensem diferente. Reativar na atualidade experiências tomadas como passadas obriga a pensar sobre o presente e pode pôr em questão nossos hábitos e certezas bem estabelecidas (Starhawk 2003:322-3).

14 É preciso fazer um adendo que mais adiante será retomado. Utilizo-me da Ciência, com C maiúsculo como grafia, próximo do sentido atribuído por Stengers. Falar da Ciência não significa atacar as práticas científicas. Se assim o fosse, provavelmente a composição que faço com a Morada da Paz, enquanto antropóloga, nem seria possível ou desejada pelas mais velhas. Trata-se, como sugere Stengers, de defender tais práticas de uma "imagem de autoridade alheia ao que constitui sua fecundidade e sua relativa confiabilidade" (Stengers 2015:63). Uma Ciência que deixa de cultivar a arte de ter cuidado, da objeção, em detrimento das certezas e comprovações, capazes de ditar "'verdadeiras' questões, as que se podem resolver 'objetivamente', e de remeter o resto à subjetividade e às suas ligações irracionais" (:65). A esse imperativo, fundante das maiores aberrações epistemicidas e etnocidas, a Morada da Paz parece se contrapor.

15 Ver Lima e Goldman (1999).

16 Dito isso, uma dupla herança se produz no interior da própria Antropologia, e aqui recupero duas citações de Goldman: "Como escrevi em outro lugar, se a antropologia faz parte do trabalho milenar da razão ocidental para controlar e excluir a diferença (na medida em que foi destinada a explicar de modo racional a falta de razão ou a desrazão dos outros e até mesmo a nossa), ela jamais se limitou a ser apenas isso. O caráter intrinsecamente paradoxal da antropologia foi explicitado há tempos por Pierre Clastres (1968), que sublinhou que o fato de que lidar com saberes dominados e mundos alternativos fez com que a antropologia, por mais enraizada 
que esteja na razão ocidental, jamais tenha conseguido se livrar de um impulso que a conduz ao diálogo com essas "linguagens estranhas" que o Ocidente não gosta de reconhecer" (Goldman 2014b). Assim como: "Como observou Stengers, o problema de uma herança não é o fato de a recebermos, mas o que fazemos com ela. Não me parece, entretanto, que a dupla herança da antropologia derive, como se costuma repetir com demasiada frequência, de sua ligação com tendências supostamente opostas do pensamento ocidental, Iluminismo e Romantismo, individualismo e holismo, racionalismo e emocionalismo. Porque tudo isso, claro, está do mesmo lado, o nosso. A originalidade da antropologia só pode provir, como Clastres (1979) também sugeriu, de seu duplo vínculo com o que ele denominava "a grande partilha entre a civilização ocidental e as civilizações primitivas" (Goldman 2014a:19).

17 Sou afetado pelas mãos desse pai do jovem, o pai cujo filho foi assassinado pela polícia e que afirma: "Mas isso aqui é munição de guerra! É munição de guerra!". Para um pai cujo filho está morrendo, não interessa se foi morto por munição de guerra ou por uma arma de calibre 38. O gesto ressalta justamente o fato de que o que importa é que se está em estado de guerra racial. E que é no interior dessa guerra racial que as diferenças efetivamente importam; que as diferenças que importam lá fora devem importar também nas nossas teorias, isto é, que a gente possa fazer antropologia em estado de guerra, como relatório de guerra, em que a guerra não possa ser facilmente lida como se fosse uma metáfora. Não estamos fazendo como se estivéssemos em guerra, há uma guerra movida contra a juventude negra! Essa é a diferença que importa. Então, os nossos mergulhos nos textos nativos não podem, sob o risco da impertinência, se descolar do estado de guerra (Anjos 2017:216).

18 Os diálogos que estabelecerei nas próximas páginas são sobretudo com Donna Haraway (1995), Isabelle Stengers e Vincianne Despret (2014) e Marylin Strathern (2006). É importante salientar que elas atuam no texto, mesmo quando não explicitamente evocadas.

19 Falam isso da pesquisa que realizei. Registrar no papel para que, em outro tempo, outras pessoas possam recuperar o que ali é experienciado, disseram-me Yashodhan e BaOgan em um momento de leitura dos meus textos. Tanto que uma das orientações que recebi de Mãe Preta foi transformar a pesquisa em um livro com uma "língua grossa", que possa ser lido de forma mais ampla, ou seja, há interesse de que aquilo que a Antropologia possibilitou, através de suas ferramentas, possa ser utilizado para instigar a troca e a criação de outras formas de resistência.

20 A vergonha também é trazida por Grada Kilomba, a partir de uma fala pública de Paul Gilroy em que descreve cinco mecanismos de defesa do ego pelos quais nós, sujeitos brancos, passamos para, enfim, sermos conscientes da nossa própria branquitude e racismo: negação, culpa, vergonha, reconhecimento e reparação. Kilomba nos diz que a vergonha "é o medo do ridículo, a resposta ao fracasso de viver de acordo com o ideal do seu próprio ego. [...] A vergonha está, portanto, conectada intimamente ao sentido de percepção. Ela é provocada por experiências que colocam em questão nossas preconcepções sobre nós mesmas/os e nos obriga a nos vermos através dos olhos de "outras/os", nos ajudando a reconhecer a discrepância entre a percepção de outras pessoas sobre nós e nossa própria percepção de nós mesmas/os" (2019:45). 
21 Herdar, prolongar, aqui, não pode ser entendido em um sentido de filiação, pois ele engendra um processo de transformação. Ser herdeira (Stengers \& Pignarre 2011) é estabelecer relação com algo muito potente, que não implica querer representar o que aconteceu, nem mesmo dar seguimento às formas e às finalidades do próprio acontecimento. É fazer reverberar toda a sua potência através de outros meios e, com isso, ser capaz de suscitar novos acontecimentos.

22 Flores (2018b), especialmente terceiro capítulo.

23 "Orientar-nos ativamente de modo fabulatório traz à tona recursos que tornam possível não cairmos nessa ladeira de reclamação impotente" (Stengers \& Despret 2014:53, tradução minha).

\section{Errata}

Neste artigo, página 30, título em inglês:

Onde se lia:

AN "WE" INTERCESSOR: WHEN ETHNOGRAPHY IS ALSO MAGIC

Leia-se:

A "WE" INTERCESSOR: WHEN ETHNOGRAPHY IS ALSO MAGIC 


\section{Referências bibliográficas}

ANJOS, José Carlos Gomes. 2017. "Comentários à Mesa Redonda 'Mestiçagens e (Contra) Mestiçagens Ameríndias e AfroAmericanas'". R@U - Revista de Antropologia da UFSCar, São Carlos, v. 9, n. 2.

CLASTRES, Pierre. 1968. "Entre o silêncio e o diálogo". In: LéviStrauss. L'arc Documentos. São Paulo: Documentos.

DELEUZE, Gilles. 2002. Espinoza filosofia prática. São Paulo: Escuta. . 2010. "Controle e Devir". In: Conversações. São Paulo: Ed. 34 2017. Espinosa e o problema da expressão. São Paulo: Ed. 34.

SPINOZA, Benedidus. 2009. Ética. Belo Horizonte: Autêntica Editora.

FAVRET-SAADA, Jeane. 2005. "Ser afetado". Cadernos de Campo, São Paulo, n. 13.

FLORES, Luiza. 2018a."'A morada é uma curandeira': o feminino enquanto força". Revista Campos, UFPR, v. 19 , n. 1.

. 2018b. Ocupar: composições e resistências kilombolas. Tese de Doutorado, Programa de PósGraduação em Antropologia Social, Museu Nacional/UFRJ.

GOLDMAN, Marcio. 2014a. "Da existência de bruxos (ou como funciona a antropologia)". R@u Revista de Antropologia da UFSCar, São Carlos, v. 6, n. 1.

. 2014b. "Dois ou três platôs de uma antropologia de esquerda". Cosmos e Contexto, n. 24. Disponível em: <http://www.cosmosecontexto.org. br/?p=2951>. Acesso em ago. 2018. GOLDMAN, Marcio \& LIMA, Tânia. 1999. "Como se faz um grande divisor?". In: Marcio Goldman, Alguma Antropologia. Rio de Janeiro: Relume-Dumará.
HARAWAY, Donna. 1995. "Saberes localizados: a questão da ciência para o feminismo e o privilégio da perspectiva parcial". Cadernos Pagu, Campinas, n. 5.

KILOMBA, Grada. 2019. Memórias da plantação: episódios de racismo cotidiano. Rio de Janeiro: Cobodó.

KOROL, Claudia \& CABNAL, Lorena. 2017. "Feminismo comunitário de Iximulew, Guatemala. Diálogos con Lorena Cabnal". In: Diálogo de saberes y pedagogía feminista: educación popular. Buenos Aires: América Libre.

NASCIMENTO, Abdias do. 1980. O Quilombismo. Petrópolis: Vozes.

SANTOS, Antônio Bispo. 2015. Colonização, Quilombos - Modos e Significações. Brasília: INCTI.

STARHAWK. 1988. Dreaming the Dark: magic, sex and politics. Boston: Beacon Press.

. 2003. Rêver l'obscure. Femmes, magie et politique. Paris: Les Empêcheurs de penser en ronde/ Le Seuil.

STENGERS, Isabelle. 2015. No tempo das catástrofes - resistir à barbárie que se aproxima. São Paulo: CosacNaify.

STENGERS, Isabelle \& DESPRET, Vinciane. 2014. Woman who make a fuss: the unfaithfull doughters of Virginia Woolf. Minneapolis: Univocal publishing.

STENGERS, Isabelle \& PIGNARRE, Philippe. 2011. Capitalist Sorcery: Breaking the spell. Basingstoke: Palgrave Macmillan.

STRATHERN, Marilyn. 2006. O Gênero da Dádiva: Problemas com as mulheres e problemas com a sociedade na Polinésia. Campinas: Ed. Unicamp. 
UM “NóS” INTERCESSOR:

QUANDO A ETNOGRAFIA TAMBÉM

É MAGIA

Resumo

O material que aqui apresento constituiu parte de minha pesquisa junto à Comunidade Kilombola Morada da Paz, situada em Triunfo/RS, formada majoritariamente por mulheres negras. As pessoas que lá residem são consideradas filhas de uma preta velha, Mãe Preta, e de um exu, Seu Sete, que guiam e orientam os caminhos da comunidade e de suas integrantes. Tudo o que ocorre no mundo faz parte do que chamam espiritualidade e participa do que chamam guerra cósmica. Minha presença no local e a escrita da tese não foram percebidas como externas a isso. Dessa forma, tanto o trabalho de campo quanto a escrita foram acompanhados minuciosamente pelas cinco mais velhas e fundadoras da comunidade, conhecidas como as Yas (as mães) e o Baba (o pai). $\mathrm{Na}$ medida em que entendem que " $a$ palavra é magia", o processo de escrita da tese produzia efeitos na comunidade que, por sua vez, interferia diretamente nele. Nesse processo, produziu-se um intercessor ao clássico recurso textual 'nós e outros' da Antropologia. Criouse um outro "nós e outros" no texto, a convite das Yas, tendo em vista a "guerra cósmica" em curso. Coube a mim traduzir, para a Antropologia, os efeitos experimentais dessa criação.

Palavras-chave: Etnografia, Cosmopolítica, Mulheres negras, Quilombo.

\section{A “WE" INTERCESSOR: WHEN ETHNOGRAPHY IS ALSO MAGIC}

\section{Abstract}

The material I present here was part of my research with the Kilombola Morada da Paz Community, located in Triunfo/RS, formed mostly by black women. The people who live there are considered daughters of an preta-velha, Mãe Preta, and an exu, Seu Sete, who guide the community and its members. Everything that happens in the world is part of what they call spirituality and participates in what they call "cosmic war". My presence in the territory and the writing of the Thesis were not perceived as external to this. In this way, both fieldwork and writing were closely followed by the five oldest and founders of the community, known as Yas (the mothers) and Baba (the father). Insofar as they understand that "the word is magic", the Thesis writing process produced effects in the community, which, in turn, directly interfered in it. In the process, an intercessor to the classic textual resource 'we and others' of Anthropology was produced. Another "we and others" was created in the text, at the invitation of Yas, in view of the ongoing "cosmic war". It was up to me to translate, for Anthropology, the experimental effects of this creation.

Keywords: Ethnography, Cosmopolitics, Black women, Quilombo. 
UN “NOSOTROS” INTERCESOR:

CUANDO LA ETNOGRAFÍA TAMBIÉN

ES MAGIA

\section{Resumen}

El material que presento fue parte de mi investigación con la Comunidad Kilombola Morada da Paz, ubicada en Triunfo/RS, formada mayoritariamente por mujeres negras. Las personas que viven allí son consideradas hijas de una Preta-vieja, Mãe Preta, y un Exu, Seu Sete, que guían los caminos de la comunidad y sus miembros. Todo lo que sucede en el mundo es parte de lo que llaman espiritualidad y participa en lo que llaman "guerra cósmica". Mi presencia en el territorio y la redacción de la Tesis no fueron percibidas como externas a esto. De esta manera, tanto el trabajo de campo como la escritura fueron seguidos de cerca por las cinco más antiguas y fundadoras de la comunidad, conocidas como Yas (las madres) y Baba (el padre). En la medida en que entienden que "la palabra es mágica", el proceso de redacción de Tesis produjo efectos en la comunidad, que, a su vez, lo interfirieron directamente en la etnografía. En el proceso, se produjo un intercesor del recurso textual clásico 'nosotros y otros' de Antropología. Otro "nosotros y otros" se creó en el texto, por invitación de Yas, en vista de la "guerra cósmica" en curso. Se me cayó a traducir, a la antropología, los efectos experimentales de esta creación.

Palabras clave: Etnografía. Cosmopolítica Mujeres negras. Quilombo. 